\title{
Clinical symptoms, comorbidities and complications features in severe and non-severe patients with COVID- 19: a systematic review and meta-analysis without cases duplication
}

\section{Zhufeng Wang}

Guangdong Hospital of Traditional Chinese Medicine

Hongsheng Deng ( $\square$ hs_deng96@126.com )

Guangzhou Medical College First Affiliated Hospital

\section{Changxing $\mathrm{Ou}$}

The first affiliated hospital of Guangzhou Medical University

Jingyi Liang

The first affiliated hospital of Guangzhou Medical University

\section{Yingzhi Wang}

The first affiliated hospital of Guangzhou Medical University

\section{Mei Jiang}

The first affiliated hospital of Guangzhou Medical University

\section{Shiyue Li}

The first affiliated hospital of Guangzhou Medical University

\section{Research}

Keywords: Coronavirus Disease 2019 (COVID-19), Severe, Meta-analysis

Posted Date: May 29th, 2020

DOI: https://doi.org/10.21203/rs.3.rs-30787/v1

License: (a) (1) This work is licensed under a Creative Commons Attribution 4.0 International License. Read Full License

Version of Record: A version of this preprint was published at Medicine on November 25th, 2020. See the published version at https://doi.org/10.1097/MD.0000000000023327. 


\section{Abstract}

Background: The pandemic of COVID-19 posed a challenge to global healthcare. The mortality rates of severe cases range from $8.1 \%$ to $31.8 \%$, and it is particularly important to identify risk factors that aggravate the disease.

Methods: We performed a systematic review of the literature with meta-analysis, using 7 databases to assess clinical characteristics, comorbidities and complications in severe and non-severe patients with COVID-19. All the observational studies were included. We performed a random or fixed effects model meta-analysis to calculate the pooled proportion and $95 \% \mathrm{Cl}$. Measure of heterogeneity was estimated by Cochran's $Q$ statistic, $I^{2}$ index and $P$ value.

Results: 4881 cases from 25 studies related to COVID-19 were included. The most prevalent comorbidity was hypertension (severe: $33.4 \%$, 95\% Cl: 25.4\% - 41.4\%; non-severe 21.6\%, 95\% Cl: 9.9\% - 33.3\%), followed by diabetes (severe: $14.4 \%, 95 \% \mathrm{Cl}: 11.5 \%$ - 17.3\%; non-severe: $8.5 \%, 95 \% \mathrm{Cl}: 6.1 \%-11.0 \%$ ). The prevalence of ARDS, AKI and shock were all higher in severe cases, with $41.1 \%$ (95\% Cl: $14.1 \%-68.2 \%), 16.4 \%(95 \% \mathrm{Cl}: 3.4 \%-29.5 \%$ ) and $19.9 \%$ (95\% Cl: $5.5 \%$ - 34.4\%), rather than 3.0\% (95\% Cl: $0.6 \%$ - 5.5\%), 2.2\% (95\% Cl: $0.1 \%-4.2 \%$ ) and $4.1 \%(95 \% \mathrm{Cl}-4.8 \%-$ $13.1 \%)$ in non-severe patients, respectively. The death rate was higher in severe cases $(30.3 \%, 95 \% \mathrm{Cl}: 13.8 \%$ $46.8 \%)$ than non-severe cases (1.5\%, $95 \% \mathrm{Cl}: 0.1 \%-2.8 \%)$.

Conclusions: Hypertension, diabetes and cardiovascular diseases may be risk factors for COVID-19 patients to develop into severe cases.

\section{Background}

Since the end of 2019, there's been a surge in cases of COVID-19 with 153517 laboratory-confirmed cases and 5735 death as of March $15^{\text {th }}$. COVID-19 exerted an adverse influence on globally, especially increasing the burden of healthcare. According to latest report[1-3], mortality rates of severe cases $(8.1 \%-31.8 \%)$ is significantly higher than general estimation of WHO (2.9\%)[4]. Severe patients often have dyspnea or hypoxemia one week after onset, which may rapidly progress to acute respiratory distress syndrome (ARDS), septic shock, metabolic acidosis that is difficult to correct, and coagulation dysfunction. Therefore, it's critical to reveal early risk factors of severe cases under the circumstance of wide-spread outbreak, which is helpful for precise treatment and prognosis improvement. Notably, previous studies have clarified that patients particularly vulnerable to severe disease are those with pre-existing medical conditions such as diabetes, cardiovascular diseases, renal failure, obesity, and immunodeficiency[5,6]. Wang et al. reported 138 cases of COVID-19 and the result indicated that almost half of hospitalized patients had comorbidities, and patients admitted to ICU with comorbidities was twice as high as without comorbidities[2]. To sum up, evaluating the prevalence of underlying diseases is fundamental to mitigate COVID-19 complications. However, this effort has been hindered by the limited number of cases and confounding classification in pre-exist studies.

The present study was undertaken to provide a systematic evaluation without cases duplication to compare the prevalence of demographic, comorbidities, symptoms, complications and outcomes between severe and nonsevere COVID-19 cases. This assessment may aid the public health sector while developing policies for surveillance and response to COVID-19 and its severe outcomes.

\section{Aims}


The followings are the aims of the study:

- To demonstrate the differences in the field of demographic, comorbidities, clinical symptoms, complications and outcomes between severe and non-severe patients with COVID-19.

- To figure out the risk factor of conversion to severe.

\section{Methods}

We registered the study protocol with PROSPERO (registration number ID: CRD42020177414) (Supplemental material: study protocol).

\section{Search strategy}

We searched PubMed, Web of Science, Cochrane Library, CBM (Chinese Biomedical), CNKI (China National Knowledge Infrastructure), WanFang, and VIP databases up to March 16, 2020. The search terms were used as follows: "Wuhan coronavirus" OR "COVID-19" OR "novel coronavirus" OR "2019-nCoV" OR "coronavirus disease" OR "SARS-CoV-2" OR "SARS2" OR "severe acute respiratory syndrome coronavirus 2"; the full search strategy is shown in Supplemental material: search strategy. The search was limited to English and Chinese language. We hand-searched included papers' reference lists and contacted experts in the field to ensure a comprehensive review.

\section{Inclusion and exclusion criteria}

We included studies which:

- Examined laboratory-confirmed patients with COVID-19.

- Examined the demographic, early comorbidities, clinical symptoms, complications, and outcomes of severe and (or) non-severe patients with COVID-19.

- Reported mean \pm SDs or proportion and 95\% confidence interval $(95 \% \mathrm{Cl})$ of these factors.

- Observational studies.

We excluded papers which:

- Did not contribute to any conducted factors of this study. (We will include the maximum sample size of the same hospital according to specific indicators. If the article does not contribute to all indicators of this study, it will be excluded even if it meets all inclusion criteria, so as to avoid the duplication of sample size.)

- Did not provide full-text.

- Did not publish in neither English nor Chinese.

\section{Screening papers}

After excluding duplicate papers, one researcher $(\mathrm{ZW})$ screened the titles and abstracts using the eligibility criteria. Then two researchers (HD, CO) assessed the rest full-text articles for eligibility. The Kappa value for study inclusion between them was 0.82 , which showed strong consistency. Consensus on the inclusion of all studies was agreed by two researchers (HD, CO) with any disagreements resolved in a discussion with researcher (ZW). 


\section{Data Extraction and synthesis}

Where available, the following information from each article was extracted using a standardized data extracted form: title, study design, study period, location, first author, publication year, sample size, sex distribution, any comorbidities, clinical symptoms, complications.

We extracted the counting data as the number of occurrences of an event versus the total number of people reported for that event $(\mathrm{n} / \mathrm{N})$. Additionally, we used the mean and standard deviation (SD), or median and interquartile range (IQR) (or median and range), to record the measurement data.

\section{Data analysis}

\section{Quality assessment and analysis}

Two researchers (CO, HD) assessed the risk of bias in individual papers using the Newcastle-Ottawa Scale (NOS) for assessing the quality of cohort studies and case-control studies[7]. This considered the domains of selection, comparability and ascertainment of the outcome of interest. A study with a score of 0-3, 4-6 and 7-9 was considered as poor, intermediate and high quality, respectively. The Weighted Kappa value was 0.67 on quality rating criteria, and consensus was reached through discussion in cases of disagreement on individual rating criteria.

\section{Statistical analysis}

All analyses were conducted using STATA Version 15 . Unit discordance for variables will be resolved by converting all units to a standard measurement for that variable. We conducted analyses by severity (severe vs non-severe). We used a random-effects model or a fixed-effects model to calculate the pooled proportion or mean and $95 \%$ confidence interval $(95 \% \mathrm{Cl})$ of all reported variables. All $P$ values were based on two-sided tests and were considered statistically significant at $\mathrm{P}<0.05$. Measure of heterogeneity, including Cochran's $\mathrm{Q}$ statistic and the $I^{2}$ index were estimated and reported. The pooled results from a random-effects model would be reported when the $I^{2}>50 \%$ and $P<0.10$, which indicated substantial heterogeneity. Publication bias was checked by visual inspection of funnel plots and tested using Egger's test when ten or more studies reported the variable, and the Egger test with $P<0.05$ was considered to be an indication of substantial publication bias.

\section{Results}

We extracted data from 25 studies reported COVID-19 cases between December, 2019 and February, 2020 (Table 1), including a total of 4881 laboratory-confirmed patients with COVID-19. The Preferred Reporting Items for Systematic Review and Meta-Analysis (PRISMA) diagram (Fig.1) describes the results of the search and reasons for excluding studies. All included studies were from hospitals in China mainland, with 12 from Hubei, 4 from Chongqing, 3 from Beijing and 1 each from Anhui, Henan, Hunan, Shanxi, Liaoning and Wenzhou. Publication bias was assessed with a funnel plot for the standard error by logit event, with no evidence of bias (Fig.2). Additionally, the Egger test $(P=0.312)$ suggested that there was no notable evidence of publication bias. We analyzed 20 variables for the meta-analysis, the following results were all presented in detail in Table 2.

\section{Comparison on demographic}


The average age was higher in severe cases as compared with non-severe cases $(48.5$ vs. $38.5, P<0.10 ; P=0.01)$. The sex ratio (male to female) was 1.33 in severe cases and 0.95 in non-severe cases. Being aged or male were considered as risk factors to severe COVID-19 (RR=1.29, 95\% Cl: 1.12 - 1.47). (Figure 3 )

\section{Comparison in comorbidities}

Prevalence of comorbidity in severe cases was remarkably higher in severe cases (58.4\%, 95\% Cl: 48.8\% - 67.9\%) than non-severe cases $(27.6 \%, 95 \% \mathrm{Cl}: 18.6 \%$ - 36.6\%) ( $P=0.00)$. Meta-analysis showed that in both groups, the most prevalent comorbidity was hypertension (severe case: $33.4 \%, 95 \% \mathrm{Cl}$ : $25.4 \%$ - 41.4\%; non-severe cases:21.6\%, 95\% Cl: 9.9\% - 33.3\%; $P=0.00$ ), followed by diabetes (severe case:14.4\%, 95\% Cl: 11.5\% - 17.3\%; nonsevere cases: $8.5 \%, 95 \% \mathrm{Cl}: 6.1 \%-11.0 \% ; P=0.00)$. With any comorbidity (RR=1.96, 95\% Cl: $1.69-2.26)$, especially diabetes ( $R R=1.53,95 \% \mathrm{Cl}: 1.29$ - 1.82), hypertension ( $R R=1.40,95 \% \mathrm{Cl}: 1.22-1.60)$, cardiovascular disease $(\mathrm{RR}=1.79,95 \% \mathrm{Cl}: 1.50-2.13)$ and $\mathrm{COPD}(\mathrm{RR}=2.10,95 \% \mathrm{Cl}: 1.70-2.58)$ were considered as risk factors to severe COVID-19. ( Figure 3 )

\section{Comparison on clinical symptoms}

Both in severe and non-severe case, the most common clinical symptom was fever (severe: $90.0 \%, 95 \%$ Cl: $86.7 \%$ 93.3\%; non-severe: $78.4 \%, 95 \% \mathrm{Cl}: 70.7 \%-86.2 \%$; $P=0.00$ ), followed by cough (severe: $69.0 \%, 95 \% \mathrm{Cl}: 60.4 \%$ 77.5\%; non-severe: $54.2 \%, 95 \% \mathrm{Cl}: 47.0 \%-61.5 \%$; $P=0.00$ ). Myalgia or fatigue (severe: $36.7 \%, 95 \% \mathrm{Cl}: 25.5 \%$ 48.0\%; non-severe: $28.8 \%, 95 \%$ Cl: $20.2 \%$ - 37.4\%; $P=0.00$ ) and sputum production (severe: $37.3 \%, 95 \% \mathrm{Cl}: 23.3 \%$ $51.3 \%$; non-severe: $23.3 \%, 95 \% \mathrm{Cl}: 18.4 \%-28.1 \% ; P=0.00)$ were almost equally prevalent in two groups. The overall proportion of clinical symptoms was about 10\%-15\% higher in severe patients (RR: 1.60 2.47). ( Figure 3 )

\section{Comparison on complications}

Severe cases have significantly higher prevalence as compared with control group for ARDS (41.1\% vs. 3.0\%, $P=0.00)$, AKI (16.4\% vs. $2.2 \%, P=0.00)$, shock (19.9\% vs. $4.1 \%, P=0.00)$. ARDS (RR=5.06, 95\% Cl: $4.08-6.27)$, AKI $(\mathrm{RR}=2.17,95 \% \mathrm{Cl}: 1.81-2.60)$ and shock $(\mathrm{RR}=3.17,95 \% \mathrm{Cl}: 2.36-4.27)$ were all risk factors to severe COVID-19. (Figure 3 )

\section{Comparison on outcomes}

The mortality was obviously higher in severe cases than non-severe cases $(30.3 \%$ vs. $1.5 \%, P=0.00)$. Severe patients were 2.30 times more likely to die than non-severe patients ( $R R=2.30,95 \% \mathrm{Cl}: 2.02-2.63$ ). ( Figure 3 )

\section{Discussion}

This is the first meta-analysis that avoids the phenomenon of included cases duplication, which compares severe and non-severe COVID-19 in the field of demographic features, clinical symptoms comorbidities, complications and outcomes. Based on 4881 laboratory-confirmed cases with COVID-19 in mainland China from 25 studies, we found that being male was more susceptible to severe COVID-19. In terms of comorbidities, patients combining diabetes, hypertension, cardiovascular disease and COPD were more likely to develop severe COVID-19, which was consistent with the findings of Guan Wei-jie et al. to some degree[31]. Fever and cough were the main clinical symptoms in both severe and non-severe cases, which was consistent with previous studies[1, 2, 32] . As for complications, ARDS, AKI or shock were much more likely to observed in severe cases, which was in accordance 
with the finding on MERS-CoV[6,33]. The death rate of severe cases was obviously higher than the WHO estimates as $2.90 \%$, while it was lower in non-severe cases.

Based on results of clinical symptoms, we found that a significant difference between severe and non-severe patients with COVID-19 on overall factors. But in clinical practice, it is difficult to conclude whether a patient is more likely to develop severe or non-severe COVID-19 based on such clinical symptoms. Nonetheless, clinical symptoms are undoubtedly essential for susceptible cases screening.

According to our analysis results on comorbidities, severe patients used to be with comorbidities on admission especially as diabetes, hypertension and cardiovascular disease, which could affect some key mediators of the host's innate immune response[33]. Previous findings on MERS-CoV also found that people with severe illness were more likely to combine these underlying comorbidities[33]. This can be explained by the phenomenon of cytokine storm that a variety of cytokines gather in the body fluids. Early studies of MERS-CoV found that the amount of Th1/Th2 cytokines profile was higher in patients with diabetes, hypertension or cardiovascular disease which was linked with exacerbation of pro-inflammatory state and generation of oxidative stress[17, 34-38]. Studies have shown that cytokine storm indicate poor prognosis and tissue damage[10]. So far in COVID-19 patients, research has shown that ICU patients had higher plasma levels of IL-2, IL-7, IL-10, GSCF, IP10, MCP1, MIP1A, and TNF-a compared with non-ICU patients[1].

Considering that these cytokines mainly belong to Th1 or Th2 subgroups, we infer that patients with comorbidities, especially those with diabetes, hypertension or cardiovascular disease, are more likely to develop severe COVID-19. Therefore, we suggest that clinicians can pay more attention to patients with comorbidities, which may prevent the development of severe COVID-19 and its progressive complications with suitable care.

Also, it is believed that cytokine storm is also an important cause of ARDS and multiple organ failure in patients with viral infections[39, 40].

Therefore, we believed that patients combined with diabetes, hypertension or cardiovascular disease were more likely to develop progressive complications, which was fatal and difficult to cure.

As mentioned on complications of severe and non-severe patients, we found that the incidence of ARDS, AKI and shock were remarkably higher in severe patients. This was also consistent with the conclusion of previous research that secondary pneumonia, ARDS, encephalitis, myocarditis and other fatal complications could occur in severe patients[6,33]. These severe clinical manifestations caused by the underlying comorbidities can also be seen in other respiratory diseases such as influenza and influenza H1N1[32, 39, 41]. With evaluating the occurrence of complications induced by SARS-CoV-2 infection, it helps us fully understand the adverse impact and disease burden of severe COVID-19.

In general, figuring out differences on comorbidities, clinical symptoms and complications between severe and non-severe patients may serves as the superb way to effectively prevent patients who are non-severe but combined comorbidities from developing severe COVID-19. Besides, due to the similarity between COVID-19 with SARS and MERS to a certain extent, we could draw some experience in the previous studies of SARS and MERS while comparing with the studies of COVID-19 as well. We hope that this assessment may aid the public health sector while developing policies for surveillance and response to COVID-19 and its severe outcomes. Also, we hope that it may aid the development of vaccination for those vulnerable people. 


\section{Strengths And Limitations}

We followed the PRISMA procedure in this meta-analysis for medical evidence searching. For the sake of data sources from each literature, we excluded the potential repeated cases from the same hospital or region according to every specific variable which we are about to conduct, avoiding to amplify the false effect of some factors by including many duplicate cases.

There are still some limitations in this study. First, all the included studies are conducted in mainland China, so the outcomes may not be suitable for the international situation at present. Second, there were some differences in the proportion of diabetes, hypertension or cardiovascular diseases between the studies, which may be a source of heterogeneity.

But these results can play a certain reference value and alert role for future epidemic prevention and treatment measures.

\section{Conclusion}

There is a significant difference between severe and non-severe patients with COVID-19 in terms of demographic features, clinical symptoms, comorbidities, complications and outcomes. Hypertension, diabetes and cardiovascular diseases may be risk factors for COVID-19 patients to develop into severe cases.

\section{Abbreviations}

COVID-19: corona virus disease 2019

SARS : severe acute respiratory syndrome

MERS-CoV: middle east respiratory syndrome coronavirus

WHO: world health organization

SD: standard deviation

IQR: interquartile range

Cl: confidence interval

RR: relative risk

ARDS: acute respiratory distress syndrome

AKI: acute kidney injury

\section{Declarations}

\section{Ethics approval and consent to participate}

No ethical approval was required for this systematic review of existing published literature. 


\section{Consent for publication}

Not applicable.

\section{Competing interests}

The authors declare that they have no competing interests.

\section{Funding}

None.

\section{Authors' contributions}

Conception and design: Mei Jiang, Shiyue Li, Zhufeng Wang, Yingzhi Wang; (II) Administrative support: Mei Jiang, Shiyue Li; (III) Collection and assembly of data: Zhufeng Wang, Hongsheng Deng, Changxing Ou and Jingyi Liang; (V) Data analysis and interpretation: Zhufeng Wang, Hongsheng Deng, Changxing Ou and Yingzhi Wang; (VI) Manuscript writing: All authors; (VII) All authors have read and approved the manuscript.

\section{Acknowledgements}

Not applicable.

\section{References}

1. Huang C, Wang Y, Li X, Ren L, Zhao J, Hu Y, Zhang L, Fan G, Xu J, Gu X et al: Clinical features of patients infected with 2019 novel coronavirus in Wuhan, China. Lancet (London, England) 2020, 395(10223):497-506.

2. Wang D, Hu B, Hu C, Zhu F, Liu X, Zhang J, Wang B, Xiang H, Cheng Z, Xiong Y et al: Clinical Characteristics of 138 Hospitalized Patients With 2019 Novel Coronavirus-Infected Pneumonia in Wuhan, China. Jama 2020.

3. Guan WJ, Ni ZY, Hu Y, Liang WH, Ou CQ, He JX, Liu L, Shan H, Lei CL, Hui DSC et al: Clinical Characteristics of Coronavirus Disease 2019 in China. The New England journal of medicine 2020.

4. Batlle D, Wysocki J, Satchell K: Soluble angiotensin-converting enzyme 2: a potential approach for coronavirus infection therapy? Clinical science (London, England : 1979) 2020, 134(5):543-545.

5. Al-Tawfiq JA, Hinedi K, Ghandour J, Khairalla H, Musleh S, Ujayli A, Memish ZA: Middle East respiratory syndrome coronavirus: a case-control study of hospitalized patients. Clinical infectious diseases : an official publication of the Infectious Diseases Society of America 2014, 59(2):160-165.

6. Assiri A, Al-Tawfiq JA, Al-Rabeeah AA, Al-Rabiah FA, Al-Hajjar S, Al-Barrak A, Flemban H, Al-Nassir WN, Balkhy $\mathrm{HH}$, Al-Hakeem RF et al: Epidemiological, demographic, and clinical characteristics of 47 cases of Middle East respiratory syndrome coronavirus disease from Saudi Arabia: a descriptive study. The Lancet Infectious diseases 2013, 13(9):752-761.

7. Wells G, Shea B, O'Connell J: The Newcastle-Ottawa Scale (NOS) for Assessing The Quality of Nonrandomised Studies in Meta-analyses. Ottawa Health Research Institute Web site 2014, 7.

8. Cheng K, Wei M, Shen H, Wu C, Chen D, Xiong W, Zhou X, Zhang D, Zheng J,: Clinical characteristics of 463 patients with normal and severe COVID-19 rehabilitation. Shanghai Medical Journal 2020. 
9. Yang X, Yu Y, Xu J, Shu H, Xia J, Liu H, Wu Y, Zhang L, Yu Z, Fang M et al: Clinical course and outcomes of critically ill patients with SARS-CoV-2 pneumonia in Wuhan, China: a single-centered, retrospective, observational study. The Lancet Respiratory medicine 2020.

10. Xu S, Hu H, Hu Y, Shui H: Clinical features of 62 cases of critical COVID-19 with acute renal injury. Medical Journal of Wuhan University 2020.

11. Bai P, He W, Zhang X, Jin J, Liu S: Clinical characteristics of 58 patients with severe and critical COVID 19. Chin J Emerg Med 2020, 29.

12. Peng YD, Meng K, Guan HQ, Leng L, Zhu RR, Wang BY, He MA, Cheng LX, Huang K, Zeng QT: Clinical characteristics and outcomes of 112 cardiovascular disease patients infected by 2019-nCoV. Chin J Cardiol 2020, 48(0):E004-E004.

13. Wen K, Li W, Zhang D, Zhang A, Zhang T, Zhao P, Qin E: Epidemiological and clinical characteristics of 46 COVID - 19 patients in Beijing. Chinese Journal of Infectious Diseases 2020, 38.

14. Xu YH, Dong JH, An WM, Lv XY, Yin XP, Zhang JZ, Dong L, Ma X, Zhang HJ, Gao BL: Clinical and computed tomographic imaging features of novel coronavirus pneumonia caused by SARS-CoV-2. The Journal of infection 2020, 80(4):394-400.

15. Wan Q, Shi A, He T, Tang L: Clinical characteristics of 153 cases infected with COVID - 19 in Chongqing area.Chin J Clin Infect Dis 2020, 13.

16. Yuan J, Sun Y, Zuo Y, Chen T, Cao Q, Yuan G, Yang M, Zhang W, Peng A, Chen Y: Clinical characteristics of 153 cases infected with COVID - 19 in Chongqing area. Journal of Southwest University(Natural Science Edition) 2020.1-7.

17. Xiong J, Jiang W, Zhou Q, Hu X, Liu C: Clinical characteristics, treatment and prognosis of 89 patients with COVID-19. Medical Journal of Wuhan University 2020.

18. Lu Z, He R, Jiang W, Fan C, Geng Q: Analysis of clinical characteristics and immune function of COVID-19 patients. Medical Journal of Wuhan University 2020.

19. Fang X, Mei Q, Yang T, Zhang L, Yang Y, Wang Y, Tong F, Ye C, Gao Y, Huang Y et al: Clinical features and treatment of 79 cases infected by COVID-19. Chinese Pharmacological Bulletin 2020, 36.

20. Xiao K, Shui L, Pang X, Mou H, Wang J, Lang C, Lv J, Sun K, Li W, Chen Y: Analysis of clinical characteristics of 143 patients with COVID-19 in northeast Chongqing. Journal of Third Military Medical University 2020.

21. Li K, Wu J, Wu F, Guo D, Chen L, Fang Z, Li C: The Clinical and Chest CT Features Associated with Severe and Critical COVID-19 Pneumonia. Investigative radiology 2020.

22. Cheng J, Huang C, Zhang G, Liu D, Li P, Lu C, Li J: Epidemiological characteristics of COVID-19 in Henan province. Chinese Journal of Tuberculosis and Respiratory Diseases 2020, 43.

23. Dai Z, Gao L, Luo K, Xiao J, Huang C, Zeng K, Liu Z, Zhao S, Yang H, Sun Q et al: Analysis of clinical characteristics of COVID-19 in Hunan province. Practical Preventive Medicine 2020, 27.

24. Gao T, He X, Su H, Zheng H, Jiang Y, Chen J, Xu X: Clinical characteristics of COVID-19 in 11 cases. Chinese Journal of Infectious Diseases 2020, 13.

25. Li D, Liu H, Wang Y, Guo H, Wang Y, Wang K, Zhao R, Wu Y, Li X: Clinical characteristics of COVID-19 in 30 cases. Chin J Infect 2020, 38.

26. Chen C, Chen C, Yan J, Zhou N, Zhao J, Wang D: Analysis of myocardial injury and cardiovascular disease in critically ill patients with COVID-19. Chin J Cardiol 2020, 48. 
27. Tian S, Hu N, Lou J, Chen K, Kang X, Xiang Z, Chen H, Wang D, Liu N, Liu D et al: Characteristics of COVID-19 infection in Beijing. The Journal of infection 2020, 80(4):401-406.

28. Zhang JJ, Dong X, Cao YY, Yuan YD, Yang YB, Yan YQ, Akdis CA, Gao YD: Clinical characteristics of 140 patients infected with SARS-CoV-2 in Wuhan, China. Allergy 2020.

29. Chen M, An W, Xia F, Yang P, Liao Y, Fang S, Xu X, Zhang M: Retrospective analysis of case data of COVID-19 patients with different clinical type. Herald of Medicine 2020.

30. Yang W, Cao Q, Qin L, Wang X, Cheng Z, Pan A, Dai J, Sun Q, Zhao F, Qu J et al: Clinical characteristics and imaging manifestations of the 2019 novel coronavirus disease (COVID-19):A multi-center study in Wenzhou city, Zhejiang, China. The Journal of infection 2020, 80(4):388-393.

31. Guan WJ, Liang WH, Zhao Y, Liang HR, Chen ZS, Li YM, Liu XQ, Chen RC, Tang CL, Wang T et al: Comorbidity and its impact on 1590 patients with Covid-19 in China: A Nationwide Analysis. The European respiratory journal 2020.

32. Akbar DH: Bacterial pneumonia: comparison between diabetics and non-diabetics. Acta diabetologica 2001, 38(2):77-82.

33. Badawi A, Ryoo SG: Prevalence of comorbidities in the Middle East respiratory syndrome coronavirus (MERSCoV): a systematic review and meta-analysis. International journal of infectious diseases : IJID : official publication of the International Society for Infectious Diseases 2016, 49:129-133.

34. Mahlangu T, Dludla PV, Nyambuya TM, Mxinwa V, Mazibuko-Mbeje SE, Cirilli I, Marcheggiani F, Tiano L, Louw J, Nkambule BB: A systematic review on the functional role of Th1/Th2 cytokines in type 2 diabetes and related metabolic complications. Cytokine 2020, 126:154892.

35. Al-Shukaili A, Al-Ghafri S, Al-Marhoobi S, Al-Abri S, Al-Lawati J, Al-Maskari M: Analysis of inflammatory mediators in type 2 diabetes patients. International journal of endocrinology 2013, 2013:976810.

36. Limonta D, Torres G, Capo V, Guzman MG: Apoptosis, vascular leakage and increased risk of severe dengue in a type 2 diabetes mellitus patient. Diabetes \& vascular disease research 2008, 5(3):213-214.

37. Kaviarasan K, Jithu M, Arif Mulla M, Sharma T, Sivasankar S, Das UN, Angayarkanni N: Low blood and vitreal BDNF, LXA4 and altered Th1/Th2 cytokine balance are potential risk factors for diabetic retinopathy. Metabolism: clinical and experimental 2015, 64(9):958-966.

38. Dharmashankar K, Widlansky ME: Vascular endothelial function and hypertension: insights and directions. Current hypertension reports 2010, 12(6):448-455.

39. Mertz D, Kim TH, Johnstone J, Lam PP, Science M, Kuster SP, Fadel SA, Tran D, Fernandez E, Bhatnagar N et al: Populations at risk for severe or complicated influenza illness: systematic review and meta-analysis. $B M J$ (Clinical research ed) 2013, 347:f5061.

40. Gupta DL, Bhoi S, Mohan T, Galwnkar S, Rao DN: Coexistence of Th1/Th2 and Th17/Treg imbalances in patients with post traumatic sepsis. Cytokine 2016, 88:214-221.

41. Kusznierz G, Uboldi A, Sosa G, Torales S, Colombo J, Moyano C, Escobar H, Lejona S, Anchart E, Gomez A et al: Clinical features of the hospitalized patients with 2009 pandemic influenza A (H1N1) in Santa Fe, Argentina. Influenza and other respiratory viruses 2013, 7(3):410-417.

\section{Tables}

Table 1. Description of 25 studies retrieved from systematic search

Page 10/17 


\begin{tabular}{|c|c|c|c|c|c|c|}
\hline $\begin{array}{l}\text { First } \\
\text { Authour }\end{array}$ & Year & Location & $\begin{array}{l}\text { Study } \\
\text { Design }\end{array}$ & $\begin{array}{c}\text { Number } \\
\text { of } \\
\text { Patients }\end{array}$ & Study period & $\begin{array}{l}\text { Quality } \\
\text { score }\end{array}$ \\
\hline $\begin{array}{l}\text { Chaolin } \\
\text { Huang[1] }\end{array}$ & 2020 & Wuhan, China (Jin-Yintan hospital) & $\begin{array}{l}\text { prospective } \\
\text { study }\end{array}$ & 41 & By Jan. 2, 2020 & 7 \\
\hline $\begin{array}{l}\text { Cheng } \\
\text { Kebin[2] }\end{array}$ & 2020 & Wuhan, China (Jin-Yintan hospital) & $\begin{array}{l}\text { retrospective } \\
\text { study }\end{array}$ & 463 & By Feb. 6, 2020 & 5 \\
\hline $\begin{array}{l}\text { Xiaobo } \\
\text { Yang[3] }\end{array}$ & 2020 & Wuhan, China (Jin-Yintan hospital) & $\begin{array}{l}\text { retrospective } \\
\text { study }\end{array}$ & 52 & $\begin{array}{l}\text { Dec. } 2019 \text { to } \\
\text { Jan. } 26,2020\end{array}$ & 6 \\
\hline $\mathrm{Xu}$ Shen [4] & 2020 & Wuhan, China (Zhongnan hospital) & $\begin{array}{l}\text { retrospective } \\
\text { study }\end{array}$ & 62 & $\begin{array}{l}\text { Jan. } 8,2020 \text { to } \\
\text { Feb. } 24,2020\end{array}$ & 5 \\
\hline $\begin{array}{l}\text { Dawei } \\
\text { Wang[5] }\end{array}$ & 2020 & Wuhan, China (Zhongnan hospital) & $\begin{array}{l}\text { retrospective } \\
\text { study }\end{array}$ & 138 & $\begin{array}{l}\text { Jan. } 1,2020 \text { to } \\
\text { Jan. } 28,2020\end{array}$ & 7 \\
\hline Bai Peng[6] & 2020 & Wuhan, China【Xiehe hospital) & $\begin{array}{l}\text { retrospective } \\
\text { study }\end{array}$ & 58 & $\begin{array}{l}\text { Jan. } 29,2020 \text { to } \\
\text { Feb. } 26,2020\end{array}$ & 6 \\
\hline $\begin{array}{l}\text { Peng } \\
\text { Yudong[7] }\end{array}$ & 2020 & Wuhan, China』Xiehe hospital) & $\begin{array}{l}\text { retrospective } \\
\text { study }\end{array}$ & 112 & $\begin{array}{l}\text { Jan. } 20,2020 \text { to } \\
\text { Feb. } 15,2020\end{array}$ & 5 \\
\hline Wen $\mathrm{Ke}[8]$ & 2020 & $\begin{array}{l}\text { Beijing, China (The Fifth Medical Center of } \\
\text { Chinese PLA General Hospital) }\end{array}$ & $\begin{array}{l}\text { retrospective } \\
\text { study }\end{array}$ & 46 & $\begin{array}{l}\text { Jan. } 20,2020 \text { to } \\
\text { Feb. } 8,2020\end{array}$ & 4 \\
\hline $\begin{array}{l}\text { Yuhuan } \\
\text { Xu[9] }\end{array}$ & 2020 & $\begin{array}{l}\text { Beijing, China (The Fifth Medical Center of } \\
\text { Chinese PLA General Hospital) }\end{array}$ & $\begin{array}{l}\text { retrospective } \\
\text { study }\end{array}$ & 59 & $\begin{array}{l}\text { Jan. } 2020 \text { to } \\
\text { Feb. } 2020\end{array}$ & 5 \\
\hline $\begin{array}{l}\text { Wan } \\
\text { Qiu[10] }\end{array}$ & 2020 & Chongqing, China (Treatment center) & $\begin{array}{l}\text { retrospective } \\
\text { study }\end{array}$ & 153 & $\begin{array}{l}\text { Jan. } 26,2020 \text { to } \\
\text { Feb. 5, } 2020\end{array}$ & 5 \\
\hline $\begin{array}{l}\text { Yuan } \\
\text { Jing[11] }\end{array}$ & 2020 & Chongqing, China (Treatment center) & $\begin{array}{l}\text { retrospective } \\
\text { study }\end{array}$ & 223 & $\begin{array}{l}\text { Jan. } 24,2020 \text { to } \\
\text { Feb. } 23,2020\end{array}$ & 6 \\
\hline $\begin{array}{l}\text { Xiong } \\
\text { Juan[12] }\end{array}$ & 2020 & $\begin{array}{l}\text { Wuhan, China (Renmin Hospital of Wuhan } \\
\text { University) }\end{array}$ & $\begin{array}{l}\text { retrospective } \\
\text { study }\end{array}$ & 89 & $\begin{array}{l}\text { Jan. 17, } 2020 \text { to } \\
\text { Feb. 20, } 2020\end{array}$ & 6 \\
\hline $\begin{array}{l}\text { Lu } \\
\text { Zilong[13] }\end{array}$ & 2020 & $\begin{array}{l}\text { Wuhan, China (Renmin Hospital of Wuhan } \\
\text { University) }\end{array}$ & $\begin{array}{l}\text { retrospective } \\
\text { study }\end{array}$ & 101 & $\begin{array}{l}\text { Jan. } 15,2020 \text { to } \\
\text { Feb. } 15,2020\end{array}$ & 4 \\
\hline $\begin{array}{l}\text { Fang } \\
\text { Xiaowei[14] }\end{array}$ & 2020 & Anhui, China & $\begin{array}{l}\text { retrospective } \\
\text { study }\end{array}$ & 79 & $\begin{array}{l}\text { Jan. } 22,2020 \text { to } \\
\text { Feb. } 18,2020\end{array}$ & 5 \\
\hline $\begin{array}{l}\text { Xiao } \\
\text { Kaihu[15] }\end{array}$ & 2020 & Chongqing, China (San-Xia hospital) & $\begin{array}{l}\text { retrospective } \\
\text { study }\end{array}$ & 143 & $\begin{array}{l}\text { Jan. } 23,2020 \text { to } \\
\text { Feb. } 8,2020\end{array}$ & 4 \\
\hline $\begin{array}{l}\text { Kunhua } \\
\text { Li[16] }\end{array}$ & 2020 & $\begin{array}{l}\text { Chongqing, China (the Second Affiliated } \\
\text { Hospital of Chongqing Medical University) }\end{array}$ & $\begin{array}{l}\text { retrospective } \\
\text { study }\end{array}$ & 83 & $\begin{array}{l}\text { Jan. } 2020 \text { to } \\
\text { Feb. } 2020\end{array}$ & 5 \\
\hline $\begin{array}{l}\text { Cheng } \\
\text { Jiuling[17] }\end{array}$ & 2020 & Henan, China & $\begin{array}{l}\text { cross } \\
\text { sectional }\end{array}$ & 1265 & $\begin{array}{l}\text { By Feb. 19, } \\
2020\end{array}$ & 3 \\
\hline $\begin{array}{l}\text { Dai } \\
\text { Zhihui[18] }\end{array}$ & 2020 & Hunan, China & $\begin{array}{l}\text { retrospective } \\
\text { study }\end{array}$ & 918 & $\begin{array}{l}\text { Jan. } 21,2020 \text { to } \\
\text { Feb. } 13,2020\end{array}$ & 4 \\
\hline $\begin{array}{l}\text { Gao } \\
\text { Ting[19] }\end{array}$ & 2020 & Shanxi, China (Xianyang central hospital) & $\begin{array}{l}\text { retrospective } \\
\text { study }\end{array}$ & 11 & $\begin{array}{l}\text { Jan. } 20,2020 \text { to } \\
\text { Feb. } 15,2020\end{array}$ & 5 \\
\hline Li Dan[20] & 2020 & Liaoning, China & $\begin{array}{l}\text { retrospective } \\
\text { study }\end{array}$ & 30 & $\begin{array}{l}\text { Jan. } 22,2020 \text { to } \\
\text { Feb. } 8,2020\end{array}$ & 6 \\
\hline $\begin{array}{l}\text { Chen } \\
\text { Chen[21] }\end{array}$ & 2020 & Wuhan, China (Tongji hospital) & $\begin{array}{l}\text { retrospective } \\
\text { study }\end{array}$ & 150 & $\begin{array}{l}\text { Jan. } 2020 \text { to } \\
\text { Feb. } 2020\end{array}$ & 5 \\
\hline $\begin{array}{l}\text { SiJia } \\
\text { Tian[22] }\end{array}$ & 2020 & Beijing, China (Emergency center) & $\begin{array}{l}\text { retrospective } \\
\text { study }\end{array}$ & 262 & $\begin{array}{l}\text { By Feb. 10, } \\
2020\end{array}$ & 5 \\
\hline $\begin{array}{l}\text { Jin-jin } \\
\text { Zhang[23] }\end{array}$ & 2020 & Wuhan, China (No.7 hospital of Wuhan) & $\begin{array}{l}\text { retrospective } \\
\text { study }\end{array}$ & 140 & $\begin{array}{l}\text { Jan. } 16,2020 \text { to } \\
\text { Feb. 3, } 2020\end{array}$ & 5 \\
\hline $\begin{array}{l}\text { Chen } \\
\text { Min[24] }\end{array}$ & 2020 & $\begin{array}{l}\text { Hubei, China (the third Renmin hospital of } \\
\text { Jianghan university) }\end{array}$ & $\begin{array}{l}\text { retrospective } \\
\text { study }\end{array}$ & 54 & $\begin{array}{l}\text { Jan. } 24,2020 \text { to } \\
\text { Feb. } 8,2020\end{array}$ & 6 \\
\hline $\begin{array}{l}\text { Wenjie } \\
\text { Yang[25] }\end{array}$ & 2020 & Wenzhou, China & $\begin{array}{l}\text { retrospective } \\
\text { study }\end{array}$ & 149 & $\begin{array}{l}\text { Jan. } 17,2020 \text { to } \\
\text { Feb. } 10,2020\end{array}$ & 6 \\
\hline
\end{tabular}

PLA People's Liberation Ar

Table 2. Meta-analysis Results 


\begin{tabular}{|c|c|c|c|c|c|c|c|c|c|c|}
\hline \multirow[b]{2}{*}{ Variable } & \multirow[b]{2}{*}{ Group } & \multirow[b]{2}{*}{ number } & \multirow[b]{2}{*}{ event } & \multirow[b]{2}{*}{$\mathrm{n}$} & \multirow{2}{*}{$\begin{array}{l}\text { Mean (y- } \\
\text { old)/ } \\
\text { Prevalence, } \\
\text { (95\% CI) }\end{array}$} & \multicolumn{3}{|c|}{ Heterogeneity } & \multicolumn{2}{|c|}{$\begin{array}{l}\text { Test for subgroup } \\
\text { differences } \\
\text { RR }\end{array}$} \\
\hline & & & & & & Q & $\mathrm{I}^{2}$ & $P$ value & $\begin{array}{l}(95 \% \\
\mathrm{CI}) \\
\end{array}$ & $P$ value \\
\hline Age & severe & 14 & - & 599 & $\begin{array}{c}48.5(42.7- \\
54.4)\end{array}$ & 823.14 & $98.4 \%$ & 0.00 & - & 0.01 \\
\hline \multirow[b]{2}{*}{ Male } & $\begin{array}{l}\text { non- } \\
\text { severe }\end{array}$ & 15 & - & 1586 & $\begin{array}{c}38.5(34.3- \\
42.6)\end{array}$ & 2530.23 & $99.4 \%$ & 0.00 & \multirow{3}{*}{$\begin{array}{l}1.29 \\
(1.12- \\
1.47)\end{array}$} & \multirow{3}{*}{0.00} \\
\hline & severe & 14 & 351 & 613 & $\begin{array}{l}57.8 \% \\
(53.9 \%- \\
61.6 \%)\end{array}$ & 13.22 & $1.7 \%$ & 0.43 & & \\
\hline \multirow{3}{*}{ Female } & $\begin{array}{l}\text { non- } \\
\text { severe }\end{array}$ & 15 & 778 & 1600 & $\begin{array}{l}48.2 \% \\
(44.6 \%- \\
51.8 \%)\end{array}$ & 26.95 & $48.0 \%$ & 0.02 & & \\
\hline & severe & 14 & 263 & 613 & $\begin{array}{c}42.4 \% \\
(38.5 \%- \\
46.2 \%)\end{array}$ & 13.50 & $3.7 \%$ & 0.41 & \multirow[t]{2}{*}{$\begin{array}{c}0.78 \\
(0.68- \\
0.90)\end{array}$} & \multirow[t]{2}{*}{0.00} \\
\hline & $\begin{array}{l}\text { non- } \\
\text { severe }\end{array}$ & 15 & 822 & 1600 & $\begin{array}{l}51.8 \% \\
(48.2 \%- \\
55.4 \%)\end{array}$ & 26.95 & $48.0 \%$ & 0.02 & & \\
\hline \multirow[t]{2}{*}{$\begin{array}{c}\text { Any } \\
\text { comorbidity }\end{array}$} & severe & 9 & 281 & 500 & $58.4 \%$ & 36.95 & $78.3 \%$ & 0.00 & \multirow{2}{*}{$\begin{array}{l}1.96 \\
(1.69- \\
2.26)\end{array}$} & \multirow[t]{2}{*}{0.00} \\
\hline & $\begin{array}{l}\text { non- } \\
\text { severe }\end{array}$ & 10 & 337 & 1061 & $\begin{array}{l}27.6 \% \\
(18.6 \%- \\
36.6 \%)\end{array}$ & 100.21 & $91.0 \%$ & 0.00 & & \\
\hline \multirow[t]{2}{*}{ Diabetes } & severe & 12 & 85 & 551 & $\begin{array}{l}14.4 \% \\
(11.5 \%- \\
17.3 \%)\end{array}$ & 9.05 & $0.0 \%$ & 0.62 & \multirow[t]{2}{*}{$\begin{array}{l}1.53 \\
(1.29- \\
1.82)\end{array}$} & \multirow[t]{2}{*}{0.00} \\
\hline & $\begin{array}{l}\text { non- } \\
\text { severe }\end{array}$ & 12 & 100 & 1189 & $\begin{array}{c}8.5 \%(6.1 \% \\
-11.0 \%)\end{array}$ & 19.85 & $49.6 \%$ & 0.03 & & \\
\hline \multirow[t]{2}{*}{ Hypertension } & severe & 13 & 188 & 569 & $\begin{array}{l}33.4 \% \\
(25.4 \%- \\
41.4 \%)\end{array}$ & 45.16 & $75.6 \%$ & 0.00 & \multirow[t]{2}{*}{$\begin{array}{l}1.40 \\
(1.22- \\
1.60)\end{array}$} & \multirow[t]{2}{*}{0.00} \\
\hline & $\begin{array}{l}\text { non- } \\
\text { severe }\end{array}$ & 13 & 277 & 1212 & $\begin{array}{l}21.6 \% \\
(9.9 \%- \\
33.3 \%)\end{array}$ & 410.13 & $97.1 \%$ & 0.00 & & \\
\hline \multirow[t]{2}{*}{$\begin{array}{c}\text { Cardiovascular } \\
\text { disease }\end{array}$} & severe & 12 & 56 & 521 & $\begin{array}{l}10.4 \% \\
(6.4 \%- \\
14.4 \%)\end{array}$ & 19.03 & $47.5 \%$ & 0.04 & \multirow[t]{2}{*}{$\begin{array}{l}1.79 \\
(1.50- \\
2.13)\end{array}$} & \multirow[t]{2}{*}{0.00} \\
\hline & $\begin{array}{l}\text { non- } \\
\text { severe }\end{array}$ & 6 & 33 & 891 & $\begin{array}{c}3.3 \%(1.1 \% \\
-5.4 \%)\end{array}$ & 20.02 & $75.0 \%$ & 0.00 & & \\
\hline \multirow[t]{2}{*}{ COPD } & severe & 8 & 31 & 413 & $\begin{array}{c}6.8 \%(4.3 \% \\
-9.2 \%)\end{array}$ & 5.73 & $0.0 \%$ & 0.45 & \multirow{2}{*}{$\begin{array}{l}2.10 \\
(1.70- \\
2.58)\end{array}$} & \multirow[t]{2}{*}{0.00} \\
\hline & $\begin{array}{l}\text { non- } \\
\text { severe }\end{array}$ & 7 & 13 & 769 & $\begin{array}{c}1.8 \%(0.8 \% \\
-2.9 \%)\end{array}$ & 1.38 & $0.0 \%$ & 0.85 & & \\
\hline Malignancy & severe & 6 & 17 & 388 & $\begin{array}{c}3.5 \%(1.6 \% \\
-5.4 \%)\end{array}$ & 4.89 & $18.3 \%$ & 0.30 & $\begin{array}{l}1.09 \\
(0.76-\end{array}$ & 0.65 \\
\hline & $\begin{array}{l}\text { non- } \\
\text { severe }\end{array}$ & 5 & 22 & 579 & $\begin{array}{c}3.7 \%(0.9 \% \\
-6.4 \%)\end{array}$ & 10.82 & $63.0 \%$ & 0.03 & $1.57)$ & \\
\hline $\begin{array}{c}\text { Chronic liver } \\
\text { disease }\end{array}$ & severe & 7 & 16 & 423 & $\begin{array}{c}3.5 \%(1.7 \% \\
-5.3 \%)\end{array}$ & 2.17 & $0.0 \%$ & 0.83 & $\begin{array}{c}0.93 \\
(0.62-\end{array}$ & 0.74 \\
\hline & $\begin{array}{l}\text { non- } \\
\text { severe }\end{array}$ & 8 & 37 & 889 & $\begin{array}{c}3.8 \%(2.5 \% \\
-5.1 \%)\end{array}$ & 5.81 & $0.0 \%$ & 0.45 & $1.42)$ & \\
\hline Fever & severe & 14 & 600 & 672 & $\begin{array}{l}90.0 \% \\
(86.7 \%- \\
93.3 \%)\end{array}$ & 23.31 & $48.5 \%$ & 0.03 & $\begin{array}{c}2.47 \\
(1.96- \\
3.10)\end{array}$ & 0.00 \\
\hline & $\begin{array}{l}\text { non- } \\
\text { severe }\end{array}$ & 16 & 1711 & 2323 & $\begin{array}{c}78.4 \% \\
(70.7 \%- \\
86.2 \%)\end{array}$ & 364.59 & $95.9 \%$ & 0.00 & & \\
\hline Cough & severe & 14 & 454 & 646 & $\begin{array}{l}69.0 \% \\
(60.4 \%- \\
77.5 \%)\end{array}$ & 82.55 & $84.3 \%$ & 0.00 & $\begin{array}{l}1.86 \\
(1.59- \\
2.16)\end{array}$ & 0.00 \\
\hline & $\begin{array}{l}\text { non- } \\
\text { severe }\end{array}$ & 16 & 1204 & 2314 & $\begin{array}{l}54.2 \% \\
(47.0 \%- \\
61.5 \%)\end{array}$ & 164.90 & $90.9 \%$ & 0.00 & & \\
\hline $\begin{array}{l}\text { Myalgia or } \\
\text { fatigue }\end{array}$ & severe & 13 & 220 & 652 & $\begin{array}{l}36.7 \% \\
(25.5 \%- \\
48.0 \%)\end{array}$ & 130.41 & $90.8 \%$ & 0.00 & $\begin{array}{l}1.60 \\
(1.40- \\
1.84)\end{array}$ & 0.00 \\
\hline & $\begin{array}{l}\text { non- } \\
\text { severe }\end{array}$ & 15 & 476 & 2234 & $\begin{array}{l}28.8 \% \\
(20.2 \%- \\
37.4 \%)\end{array}$ & 416.18 & $96.6 \%$ & 0.00 & & \\
\hline Sputum & severe & 9 & 192 & 492 & $37.3 \%$ & 88.94 & $91.0 \%$ & 0.00 & 1.68 & 0.00 \\
\hline
\end{tabular}




\begin{tabular}{|c|c|c|c|c|c|c|c|c|c|c|}
\hline \multirow[t]{2}{*}{ production } & & & & & $\begin{array}{l}(23.3 \%- \\
51.3 \%)\end{array}$ & & & & \multicolumn{2}{|l|}{$\begin{array}{l}(1.44- \\
1.96)\end{array}$} \\
\hline & $\begin{array}{l}\text { non- } \\
\text { severe }\end{array}$ & 9 & 420 & 1723 & $\begin{array}{l}23.3 \% \\
(18.4 \%- \\
28.1 \%)\end{array}$ & 35.20 & $77.3 \%$ & 0.00 & & \\
\hline \multirow[t]{2}{*}{ ARDS } & severe & 4 & 67 & 144 & $\begin{array}{c}41.1 \% \\
(14.1 \%- \\
68.2 \%)\end{array}$ & 43.54 & $93.1 \%$ & 0.00 & \multirow[t]{2}{*}{$\begin{array}{l}5.06 \\
(4.08- \\
6.27)\end{array}$} & \multirow[t]{2}{*}{0.00} \\
\hline & $\begin{array}{l}\text { non- } \\
\text { severe }\end{array}$ & 5 & 7 & 360 & $\begin{array}{c}3.0 \%(0.6 \% \\
-5.5 \%)\end{array}$ & 1.37 & $0.0 \%$ & 0.50 & & \\
\hline \multirow[t]{2}{*}{$\begin{array}{l}\text { Acute kidney } \\
\text { injury }\end{array}$} & severe & 4 & 36 & 170 & $\begin{array}{l}16.4 \% \\
(3.4 \%- \\
29.5 \%)\end{array}$ & 21.56 & $86.1 \%$ & 0.00 & \multirow[t]{2}{*}{$\begin{array}{l}2.17 \\
(1.81- \\
2.60)\end{array}$} & \multirow[t]{2}{*}{0.00} \\
\hline & $\begin{array}{l}\text { non- } \\
\text { severe }\end{array}$ & 4 & 6 & 211 & $\begin{array}{c}2.2 \%(0.1 \% \\
-4.2 \%)\end{array}$ & 2.23 & $10.2 \%$ & 0.33 & & \\
\hline \multirow[t]{2}{*}{ Shock } & severe & 3 & 17 & 80 & $\begin{array}{l}19.9 \% \\
(5.5 \%- \\
34.4 \%)\end{array}$ & 5.29 & $62.2 \%$ & 0.07 & \multirow[t]{2}{*}{$\begin{array}{l}3.17 \\
(2.36- \\
4.27)\end{array}$} & \multirow[t]{2}{*}{0.00} \\
\hline & $\begin{array}{l}\text { non- } \\
\text { severe }\end{array}$ & 3 & 4 & 188 & $\begin{array}{c}4.1 \% \\
(-4.8 \%- \\
13.1 \%)\end{array}$ & 2.70 & $62.9 \%$ & 0.10 & & \\
\hline \multirow[t]{2}{*}{ Hospitalization } & severe & 7 & 149 & 295 & $\begin{array}{l}53.9 \% \\
(32.6 \%- \\
75.3 \%\end{array}$ & 109.43 & $94.5 \%$ & 0.00 & \multirow{2}{*}{$\begin{array}{c}0.90 \\
(0.74- \\
1.10)\end{array}$} & \multirow[t]{2}{*}{0.31} \\
\hline & $\begin{array}{l}\text { non- } \\
\text { severe }\end{array}$ & 7 & 439 & 814 & $\begin{array}{c}48.9 \% \\
(28.7 \%- \\
69.1 \%)\end{array}$ & 245.86 & $97.6 \%$ & 0.00 & & \\
\hline \multirow[t]{2}{*}{ Discharge } & severe & 7 & 89 & 295 & $\begin{array}{l}30.4 \% \\
(13.4 \%- \\
47.4 \%)\end{array}$ & 90.02 & $93.3 \%$ & 0.00 & \multirow[t]{2}{*}{$\begin{array}{c}0.60 \\
(0.48- \\
0.75)\end{array}$} & \multirow[t]{2}{*}{0.00} \\
\hline & $\begin{array}{l}\text { non- } \\
\text { severe }\end{array}$ & 7 & 374 & 814 & $\begin{array}{l}50.6 \% \\
(30.5 \%- \\
70.6 \%)\end{array}$ & 241.00 & $97.5 \%$ & 0.00 & & \\
\hline \multirow[t]{2}{*}{ Death } & severe & 7 & 77 & 267 & $\begin{array}{l}30.3 \% \\
(13.8 \%- \\
46.8 \%)\end{array}$ & 103.70 & $94.2 \%$ & 0.00 & \multirow[t]{2}{*}{$\begin{array}{l}2.30 \\
(2.02- \\
2.63)\end{array}$} & \multirow[t]{2}{*}{0.00} \\
\hline & $\begin{array}{l}\text { non- } \\
\text { severe }\end{array}$ & 4 & 9 & 308 & $\begin{array}{c}1.5 \%(0.1 \% \\
-2.8 \%)\end{array}$ & 4.86 & $38.2 \%$ & 0.18 & & \\
\hline
\end{tabular}

\section{Figures}



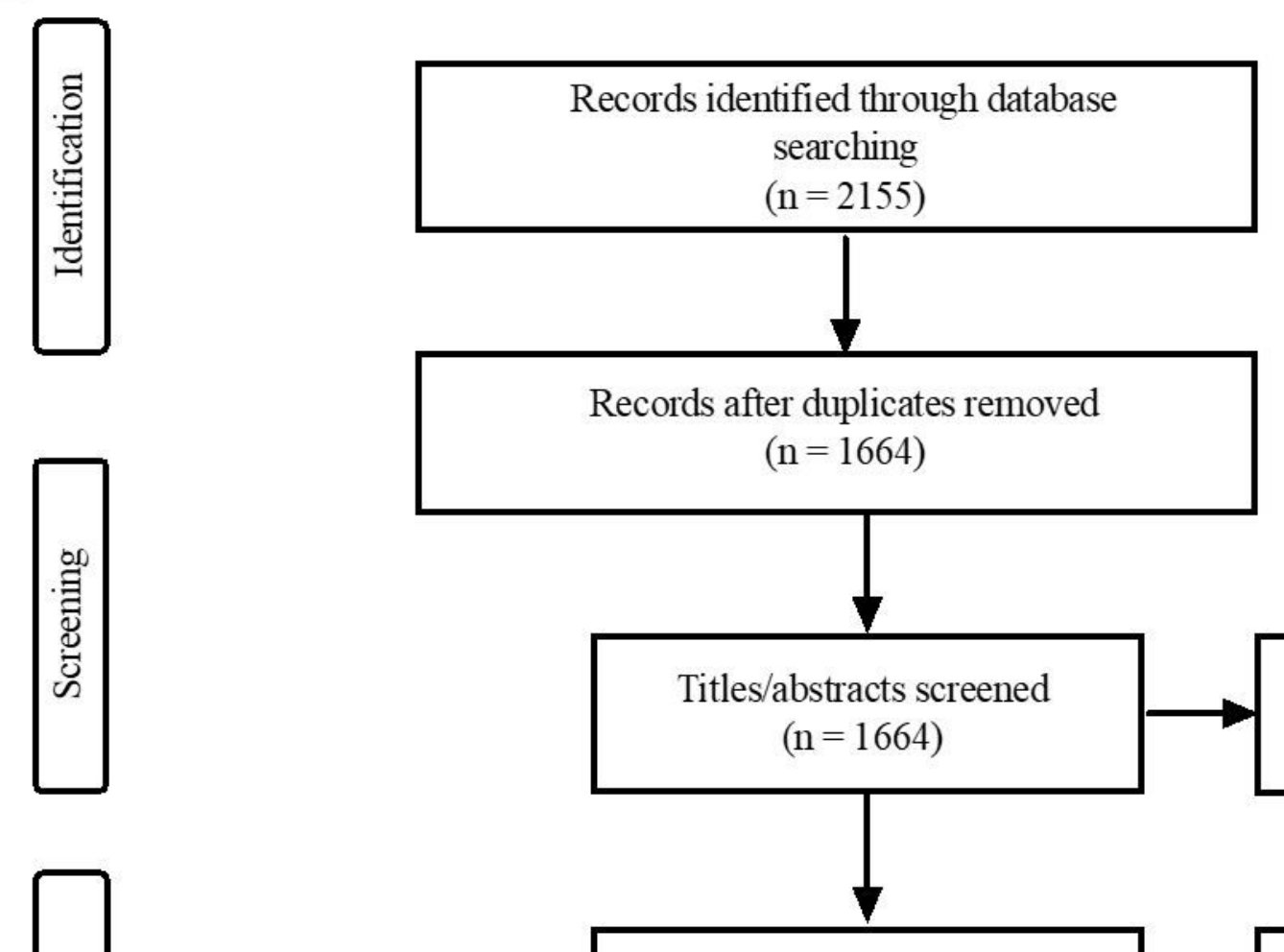

Titles/abstracts excluded $(\mathrm{n}=1541)$
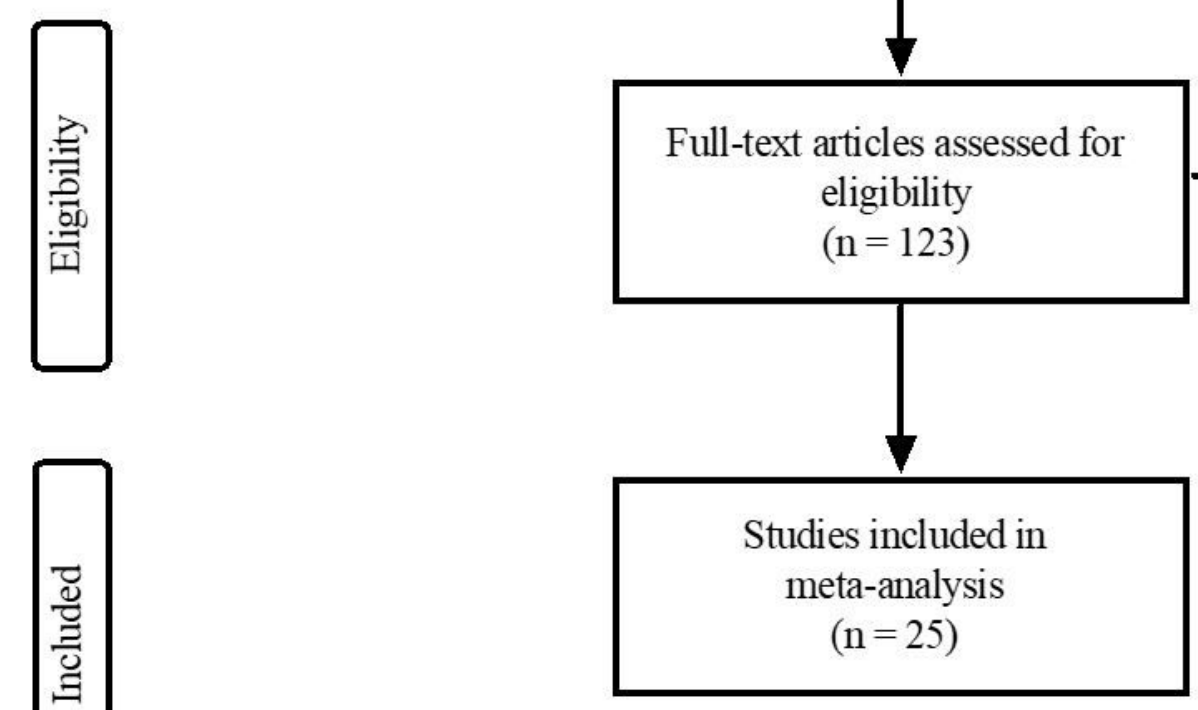

Full-text articles excluded, with reasons: no relevant data, reviews, case reports, comments, meta-analysis, etc.

$$
(n=98)
$$

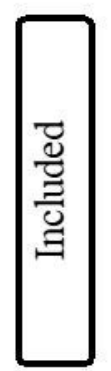

Studies included in meta-analysis

$$
(\mathrm{n}=25)
$$

Fig. 1 PRISMA flow diagram of included studies

Figure 1

PRISMA flow diagram of included studies 


\section{Funnel plot with pseudo 95\% confidence limits}

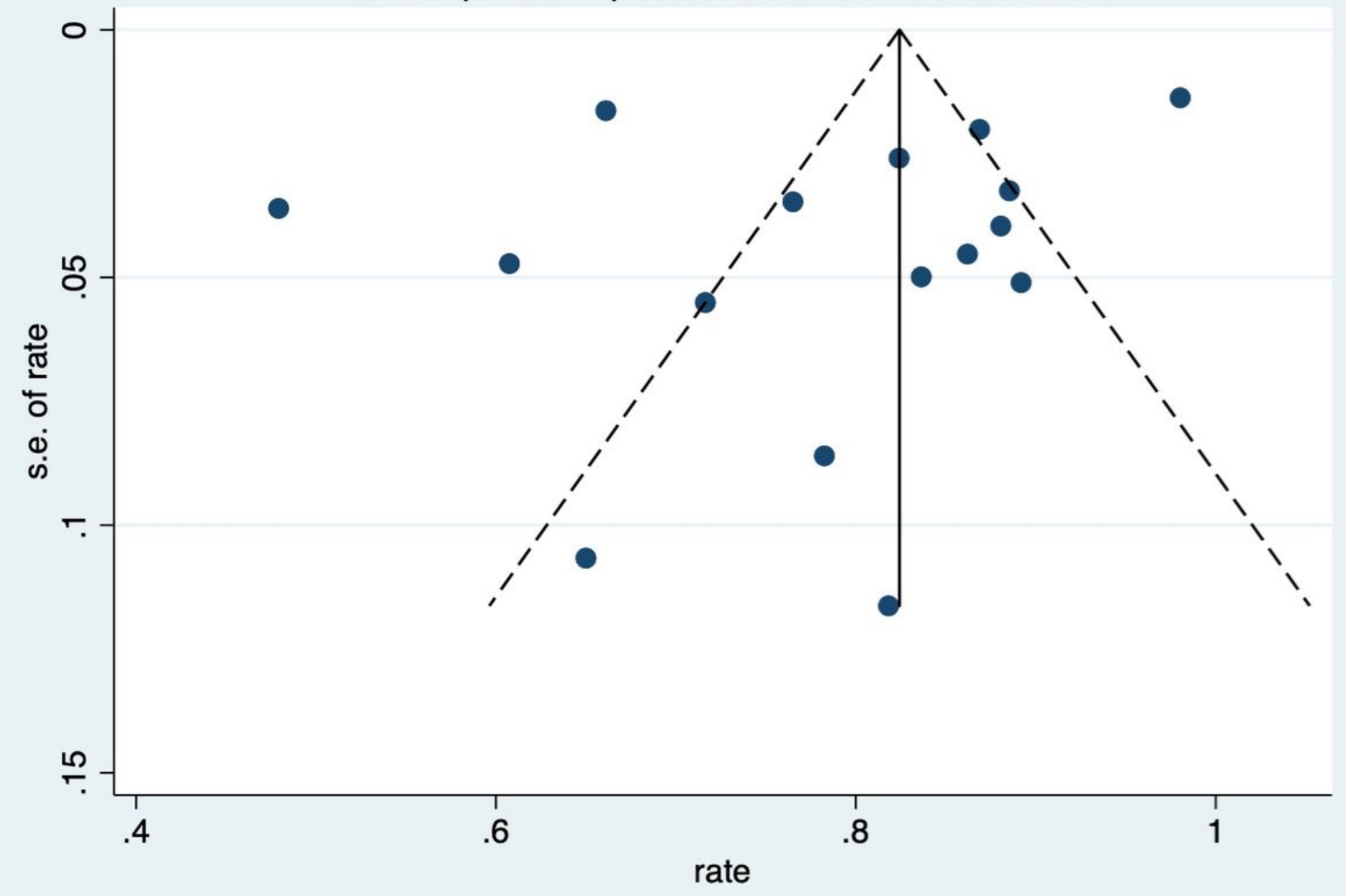

Figure 2

Funnel plot for the standard error by logit event that assess publication bias 


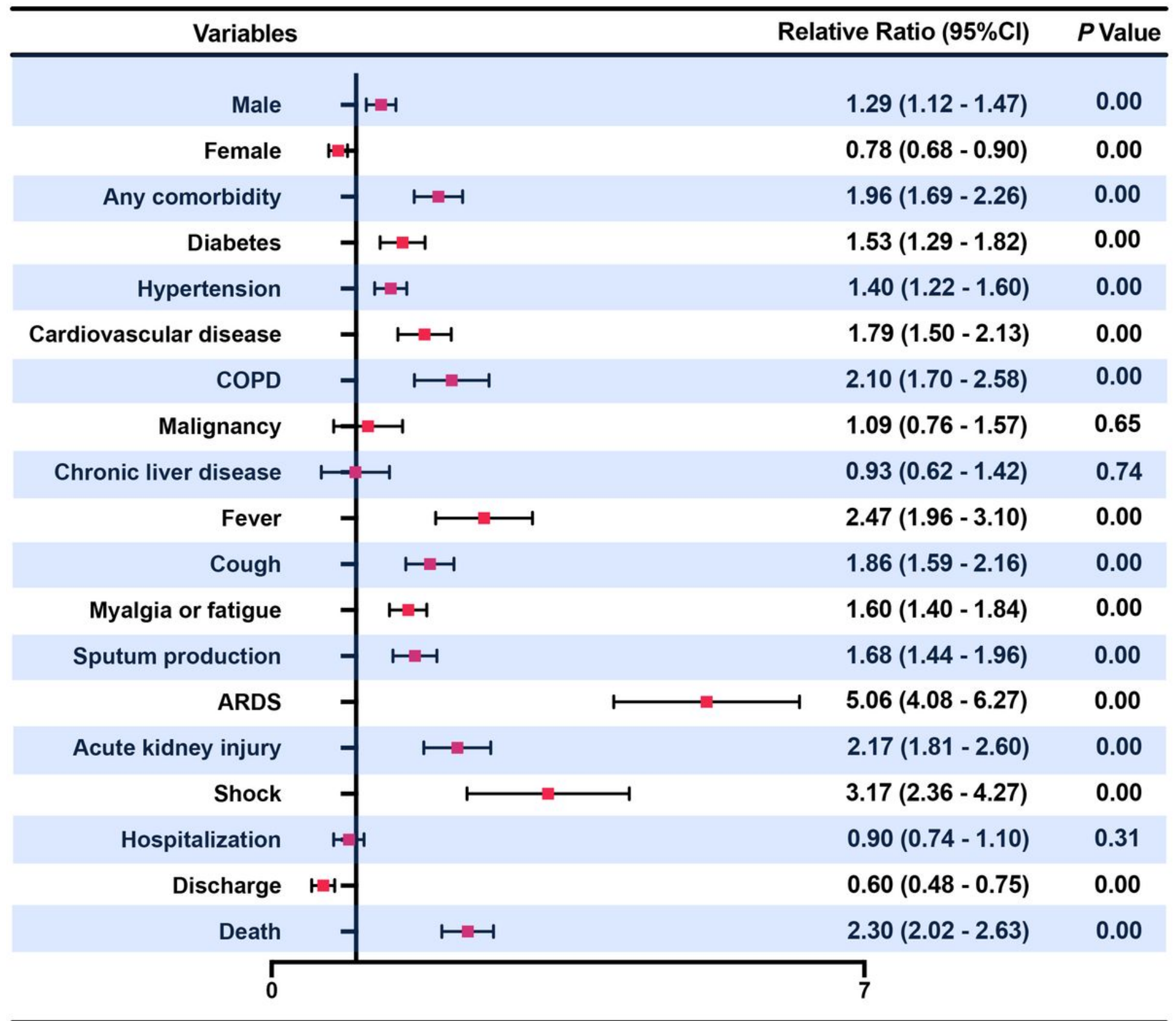

Figure 3

The Relative Ratio (RR) and the $95 \%$ confidence interval $(95 \% \mathrm{Cl})$ for the factors associated with the severe COVID19.

\section{Supplementary Files}

This is a list of supplementary files associated with this preprint. Click to download.

- FigureS4.tif

- Figures4.tif

- Figures4.tif

- FigureS5.tif 
- FigureS5.tif

- FigureS5.tif

- Figures6.tif

- FigureS6.tif

- FigureS6.tif

- Figures7.tif

- FigureS7.tif

- FigureS7.tif

- Figures8.tif

- FigureS8.tif

- Figures8.tif

- Figures9.tif

- Figures9.tif

- Figures9.tif

- FigureS10.tif

- FigureS10.tif

- FigureS10.tif

- searchstrategy.pdf

- searchstrategy.pdf

- searchstrategy.pdf

- studyprotocol.pdf

- studyprotocol.pdf

- studyprotocol.pdf 